\title{
Crude Oil Price Dwindling and the Nigerian Economy: A Resource-Dependence Approach
}

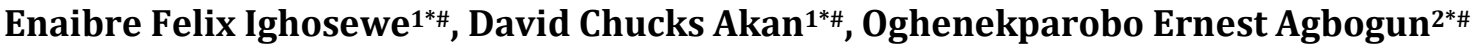 \\ ${ }^{1}$ Accounting, Banking and Finance Department, Asaba Campus, Delta State University, Asaba, Nigeria \\ ${ }^{2}$ Banking and Finance Department, University of Benin, Benin, Nigeria \\ Email: ^felixighosewe@yahoo.com, ^david.akan78@gmail.com, ^agbogunernest93@gmail.com
}

How to cite this paper: Ighosewe, E.F., Akan, D.C. and Agbogun, O.E. (2021). Crude Oil Price Dwindling and the Nigerian Economy: A Resource-Dependence Approach. Modern Economy, 12, 1160-1184. https://doi.org/10.4236/me.2021.127061

Received: June 2, 2021

Accepted: July 25, 2021

Published: July 28, 2021

Copyright $\odot 2021$ by author(s) and Scientific Research Publishing Inc. This work is licensed under the Creative Commons Attribution International License (CC BY 4.0).

http://creativecommons.org/licenses/by/4.0/

\begin{abstract}
This study examined the effect of Crude Oil Fluctuation and the Nigerian economy: A resource-dependence approach covering a study period of 35 years (1984-2018). Variables used include Fluctuation in Oil Price per Barrel (FOBP), Diesel Pump Price Fluctuations (PPPF), Petrol Pump Price Fluctuations (DPPF), Kerosene Pump Price Fluctuation (KPPF), and Real GDP. The data were gotten from the CBN Statistical Bulletin, World Bank Report, and Oil Producing Exporting Countries Annual Report while it was analyzed using Auto-Regressive Distributed Lag Model. Various diagnostic tests proved that the model is fit for the study. Accordingly, the trend analysis appears to cast doubts on whether crude oil fluctuation made significant contributions to the Nigerian economy. However, the Pearson correlation coefficient substantially attests to a strong linear relationship between the regressed and the regressors. Particularly, the individual results restated that in the short run only Fluctuation in Oil Price per Barrel (FOBP) improved the Nigerian economy significantly. However, in the long run, both Fluctuation in Oil Price per Barrel (FOBP) and Kerosene Pump Price Fluctuation (KPPF) improve the Nigerian economy significantly. Hence we conclude that, if the Nigerian economy must experience outstanding performance, both the private and public agencies should not interfere in the apex bank surveillance on the excess crude account. More so, the federal government should endeavor to industrialize the Nigerian economy.
\end{abstract}

\section{Keywords}

Crude Oil Fluctuation, Economic Performance, Nigeria,

Resource Dependence Approach

${ }^{\#}$ Enaibre Felix Ighosewe (PhD), David Chucks Akan (FCA, PhD), Oghenekparobo Ernest Agbogun (Master's Student). 


\section{Introduction}

Crude oil is popularly known as fossil fuel or better still "oil" is a naturally occurring substance that is found in widely differing quantities in different parts of the world. Although it does not have any desirable quality in its raw state when it is refined into different products (petroleum motor spirit, diesel fuels, jet fuels, and petroleum gas) it becomes useful. By its nature, it is highly volatile, highly deflectable, and highly capital intensive. Since its discovery in Oloibiri, Bayelsa State, Nigeria in 1956 by Shell B.P, it has continually sharpened the Nigerian economic and political trajectory. In like manner, it has helped to reduce the poverty level in the country through the provision of infrastructures which has fastened the growth and development process. Of course, the returns from natural gas exploitations have enabled the country to experience a post-current account surplus over the years (Ogbonna \& Orlu, 2017). Reportedly, $80 \%$ of Nigeria's energy revenues go to the national government, $16 \%$ cover operational costs while investors get the remaining $4 \%$ as returns on investment (Okonkwo \& Mojekwu, 2018).

Accordingly, increased oil prices in the early 1970s led to the enormous development of the Nigerian economy. However, hopes that the Nigerian economy will gather the strong growth momentum as it was in the early '70s are less likely in present times. This is because economic growth was driven by the rapid expansion of oil production capacity as well as massive public sector investment in the oil and gas sector. Again, the crude oil price is more prone to a series of fluctuations now than then. For example, Brent oil price fell from $\$ 114.91$ on January 31st, 2014 to $\$ 102.12$ on May 31st, 2014, and stood at $\$ 57.8$ and $\$ 67.6$ on March 31st, 2015. (Keji, 2018) opined that, these slumps alongside subsequent especially in the areas of industrial sector's development, foreign reserve management, currencies crisis management, reduction in government revenue, and ultimately, threat in terms of the country's inability to pay off all outstanding foreign debt holding.

Most assuredly, since the mono-product growth strategies adopted by the $\mathrm{Ni}$ gerian government appear to be ineffective, policy analysts then advise developing countries like Nigeria to hedge against the negative effect of oil price fluctuation on its economy by diversifying its economy. But the issue here is: is oil price fluctuation the reason why the Nigerian economy is yet to be developed or what then is the real cause? Again, a painstaking appraisal of the cyclical effect of crude oil price dwindling on economic growth reports converging and concaving results. Hence, the present study fills the research gap in extant studies by clarifying our understanding of the crude oil price slump in terms of the magnitude of its impact on economic growth. To this end, the present study examined the effect of crude oil price shock on economic growth in Nigeria. Specifically, the study sought to evaluate how fluctuation in oil price per barrel, fluctuation in the Petrol pump price, fluctuation in Diesel pump price, and fluctuation in Ke- 
rosene pump price impact real gross domestic product in Nigeria from 1984 to 2018.

Although many are of the strong assertions that crude oil fluctuation is detrimental to economic performance, our major argument is that the issue is not on crude oil fluctuation itself but on how efficient the management process is and on how efficient the Nigerian refineries are. Consequently, if these contending issues are handled adequately, the Nigerian economy will trend amidst fluctuations. The present study is both theoretically and empirically useful in that it is targeted at validating theoretical postulations and empirical findings on the subject matter. Also, the study will serve as resource material to policy analysts, government agencies, researchers, and the likes.

\section{Literature Reviews}

This section covers the conceptual framework, theoretical framework, empirical reviews, and the literature gap.

\subsection{Conceptual Framework}

The term "crude oil price dwindling" is of great concern to most economies because a sudden hike in prices has been found to cause a fall in global output. However, the construct does not have a universally acceptable definition. This is because of its multi-facet nature in that it may be also referred to as oil price shock, changes, volatility, fluctuations, or variations as the case. In trying to define the construct, researchers have viewed the construct from two viewpoints-Supply and demand sides. (Ogiri et al., 2013) defined oil-price dwindling as an inward shift in the supply curve for crude oil that is triggered by political events exogenous to the oil market and the macro-economy within a period, such as a day, a week, a month or a year. In other words, (Baumeister \& Kilian, 2016) viewed oil price fluctuations as unanticipated components of a substantial change in the price of oil, defined as the difference between the expected and realized oil price. In the same vein (Nwanna \& Eyedayi, 2016), oil price dwindling as a large unanticipated change in world economic conditions which impacts upon a national economy which could come in form of a shift in the terms of trade, a slowdown in the growth of world export demand and an increase in interest rates set by world financial markets. In the simplest term, oil price dwindling could boost economic growth in that it could make the price of crude oil at the international market to appreciate at the expense of domestic oil prices.

(Manasseh et al., 2019) viewed oil price fluctuation or variation or oscillation as the persistent upward or downward swing in the prices of oil over a long time followed by periods in which the price of oil in the international market is relatively calm. Such swings are usually caused by either demand or supply side of the international oil market resulting from political upheavals in the oil-rich middle-east, and the growing oil demand in Asian countries. 
(Keji, 2018) opined that oil price swing entails disruptions in the smooth flow of commodities across different markets. The author added that for such abnormally to be corrected, it requires such a nation must be abreast with efficient energy policy. Further, identifiable factors which led to series of slumps so far include a rise in demand in emerging economies, global financial crises, strikes, wars, and decreased oil production, reduction in global investment in the industry; lack of refinery expansion capacity; supply bottlenecks and risk related with domestic problems (for example, Nigeria), and international politics (Iraq, Iran, Russia, and Venezuela) and commoditization of world oil (Donwa et al, 2015). Other identifiable factors include selfishness, ignorance, poor institutional framework, corruption and nepotism, mismanagement and embezzlement of public funds by public office holders at all levels of government. Also, many efforts were not taken to diversify the economy in anticipation of possible negative shocks (Oyeyemi, 2013). More explicitly, (Nwanna \& Eyedayi, 2016) categorized these factors into the demand side, supply side, geographical and other considerations. His viewpoints are discussed below:

Demand Side: As countries develop, industrialization, rapid urbanization, and increase their citizenry's living standards, their oil demand will increase as well. As such, if the demand for crude oil is perfectly inelastic to variation in the oil price level, it will in turn increase import bill for the net oil-importing economies at the aggregate level (Udoka \& Nkamare, 2014). This situation will lead to a higher trade deficit and will consequently cause a deterioration of the country's current account balance (Apere \& Ijeoma, 2013). These impacts will also have further significant, negative effects and serious consequences on the country as a whole in terms of its impact on all the macro-indicators (employment rate, inflation rate, trade balance, stock market prices, and exchange rates).

(Keji, 2018) opines that continuous demand for oil by the most developed nations like the US, Canada, Japan, and others will further deepen the fortunes of oilproducing countries especially Sub-Saharan African countries. Currently, oil demand growth is highest in developing countries (Aremo et al., 2012). Nonetheless, the United States remains the world's largest oil consumer. According to the United States Energy Information Agency (EIA), transportation accounts for twothirds of oil consumed in the US. The second-largest oil consumer is China. As of 2011, China's oil consumption growth rated accounted for half $(1 / 2)$ percentage of the global oil consumption growth (EIA, 2011). China's oil consumption is distributed between power generation, economic growth, transportation sector shifts, trade, and refining capabilities. This suggests an oil addiction on the part of these economies. More than the need for transportation purposes, this addiction is partially explained by their industrial needs. Industrial demand for oil to produce chemicals, manufacture plastics, and for power generation affects the oil demand. Most advanced economies are built on a substantial industrial sector and rely heavily on transportation powered by internal combustible engines; hence, they have a higher demand for oil than less industrialized economies. 
1) Supply Side: The supply for crude oil is divided into two (2) main categories, OPEC and non-OPEC suppliers. OPEC (Organization of the Petroleum Exporting Countries) is a permanent, intergovernmental organization, established in Baghdad, Iraq, in September 1960. OPEC now comprises twelve (12) members which include: Venezuela, United Arab Emirates, Qatar, Saudi Arabia, Nigeria, Libya, Kuwait, Islamic Republic of Iran, Iraq, Ecuador, Angola, and Algeria. The Organization has its head office in Vienna, Austria. On the other hand, the main non-OPEC oil producers are; Russia, the USA, Mexico, China, Canada, Brazil, and Norway. Oil producers operating outside OPEC are responsible for producing sixty percent of the world's oil, yet they do not have much power over oil pricing. This is because non-OPEC oil reserves are only $18.67 \%$ of the global crude oil reserve therefore their current production level is deemed unsustainable in the long run due to their relatively small reserves and it is expected to decline sharply in the future.

The (World Bank Report, 2015) sub-divided the supply side of crude oil fluctuation into exogenous and endogenous. While the exogenous factor accounts for factors outside the oil market, endogenous factors account for factors that affect the global oil market daily. Notably, these two factors either affect oil production positively or negatively.

2) Geopolitical and Other Considerations: Oil prices are always vulnerable to short-term disruption caused by the weather, strikes, or conflict. Notably, both the Iranian revolution and the Iran-Iraq War doubled the crude oil prices dwindling. For example, crude oil price amounted to $\$ 35$ per barrel as of 1981 against $\$ 14$ per barrel as of 1978. Since then there have been major effects both in Iran and other countries like Libya and more recently concerning Yemen.

In Nigeria, experience has shown that adjustment in PMS pump price has been on the increase (upward trend) from 1970 to date. For example, crude oil price amounted to 70k per barrel as of 1990 as against 20k per barrel as of 1982 . Meanwhile, from 1992 to 2013, it rose to N97. The fluctuation is further evident in the drop in oil price from $\$ 114$ to a price below $\$ 50$ in 2015; a drop that continued to $\$ 35$. To further substantiate this claim, (Ogbonna \& Orlu, 2017) submitted that, the rationale behind the adjustments of the PMS products upwardly for decades is to eliminate fuel consumption subsidy following the free market system.

(Akinleye \& Ekpo, 2013) argued that it is more cost-effective to import refined petroleum outside the country than when produced locally since local factories were serviced by the federal government. According to them, this paradoxical situation has devalued the Nigerian currency and has also degraded the economic outlook of other countries. (Adugbo, 2016) reported that oil revenue mismanagement is the major reason for importing refined petroleum.

(Ujunwa, 2015) asserts the nature and degree of such an increase will depend on the structural characteristics of an economy even among the oil-importing countries. For example, the countries that engage more in the oil trade, rely 
heavily on fossil fuels, and/or use the energy intensively in industrial production are likely to be more exposed to oil price volatility on global commodity markets. To further substantiate this claim, (Rentschler, 2013) argues that, developing countries typically have large industrial sectors (which rely on oil as a production factor), large fossil fuel shares in their energy mix, and energy-inefficient technologies-these exposes them to the susceptibility of the negative effects of volatile oil prices. This implies that, depending on the nature of fluctuation, it may either contribute positively or negatively to a nation's economy (Ogbonna \& Appah, 2012). Among the positive contributions is a source of revenue to the government, transformation, and addition to the balance of payment, increase in external trade, increase in Gross Domestic Product, source of employment, transfer of technology, provision of internal energy requirements increased income per capita, and development of the economy say by providing infrastructure, industry, health facilities, educational supports, transportation and agricultural development (IMF, 2016; CBN, 2014).

(Usman et al., 2015) argued that Petroleum production and export is instrumental to the Nigerian economy since it accounted for about $90 \%$ of its gross earnings. For instance, as of 1st of January, 2009, crude oil and the natural gas reserve were estimated at 36.2 billion and 182.4 trillion cubic feet (tcf) respectively. Meanwhile, Nigeria was ranked as the 12th biggest oil-producing country in the world with 2.4 million barrels per day (BPD) or $3.1 \%$ of the estimated world total in 2008. However, (Husan et al., 2015) stated that it is a known fact that persistent rise in oil price fluctuation over time lead to increased price uncertainty for all countries irrespective of their trade balance thereby reducing planning horizons, causing firms to postpone investments, and potentially requiring expensive reallocation of resources. In like manner, the formulation of robust national budgets becomes more difficult.

(Mustapha \& Sulaiman, 2015) noted that the continuous dwindling in oil price in the global oil market has been a major issue facing oil-producing countries which in turn has dampened both their revenue generation and developmental process. A case in mind is Nigeria's economy. The oil price glut globally has become one of the biggest challenges deterring the Nigerian economy apart from unrest/insecurity (Akinlo, 2012; Udoh, 2014; Adugbo, 2016).

Globally, evidence reveals that the mineral exporting countries have been witnessing disappointing economic records. Twelve of the world's 25, most mineral dependent states and six of the most oil-dependent countries are classified as Highly Indebted Poor Countries by the World Bank. When taken as a group, all "petroleum-rich" less developed countries have witnessed a severe decline in the living standards of their populations and many of them currently rank in the bottom one-third of the United Nations Human Development Index. In addition to poor growth records and entrenched poverty, they are characterized by a high level of corruption and a low prevalence of democratization, all of which act to create high risks of civil war. 


\subsection{Theoretical Framework}

Scholars have used different theories to underpin their studies. However, for this study, the Dutch Disease Theory, Rent-Seeking Theory, Structural Theory, and rational expectation theory were used to underpin the study. The Dutch Disease Theory was formulated to explain the poor economic growth of the Netherlands following the discovery of North Sea oil. The Dutch Disease Theory (DDT) discourses when there is a boom of natural resources it results in the exchange rate of a country to appreciate, the effect of this is that the manufacturing export becomes less competitive. (Ismail, 2021) views Dutch disease as a situation by which the natural resource sector which once experiences boom experience shrinkage.

The effect of Dutch disease on the economy was divided by (Corden \& Neary, 1982) into two effects, specifically, the resource movement effect (RME) and the spending effect (SPE). The RME causes wage rate increase due to the price increase of a discovered natural resource. This is so because the price increase of the natural resource increases the value of the marginal product of the value of the resource. This causes the tradable sectors to shrink possibly in operation, some of which might perhaps shut down. However, the SPE explains that oil price revenue will only increase if its price dramatically increases. This increase will then open the way for an increased importation alongside what is absorbed domestically concerning items that tradable and non-tradable.

Contextually, the theory states that increased oil prices on a general outlook can shift the industrial structure of an oil-exporting country. Further, increased oil revenues increase the value of a domestic currency, increase importation of consumer goods but tend to reduce the competitiveness of the local producers.

Furthermore, the rent-seeking theory reinforces the DDT; familiarized by (Krueger, 1974). According to (Arnason, 2008), rent-seeking is the process of the disbursements of money and, time beyond the production of real goods and services to pushing for alteration in the policies of the Government so that profit can be maximized. These changes could be in the area of enforcing the use of certain specialized services, subsidies on certain outputs, etc. This theory, therefore, espouses the fact that the politicians enrich themselves via rent-seeking (Ross, 2001). Structural shocks theory holds that sudden large changes in the prices of food and oil could be attributed to macroeconomic fluctuations (Sommer, 2002). However, there is a sharp disagreement among the structuralist theorists on the effect of structural shocks. Some argue that in the short run, supply shocks have a transitory effect on the macro-economy (Ball \& Mankiw, 1995; Lee et al., 1995). Some others believe that for the government to address economic recession, they should not respond to adverse pressures from food and oil prices since they are highly volatile (Armando, 2009). Instead, they should focus on "the second-round effect", which is likely to be more prolonged and could result in an economic recession (Inflation Report, 2006). 
Furthermore, (Fischer, 1985) suggests there is no need for policymakers to focus on structural shocks at all since there is no provision for real wage resistance payable to employees. Some other structural shocks could be consistent and are bent in challenges of in-elastic supply in the oil and agricultural sectors (Pindyck, 1979). In their view, oil, agriculture, foreign trade, and government sectors suffer from institutional rigidities that cause prices to rise with economic developments. Hence, they suggested the removal of such institutional inflexibilities as a means through which the adverse effects of such shocks can be curbed.

The above views were opposed by proponents of the rational expectation theory (Sommer, 2002). They believe that the supply-side of fluctuation is dependent on behavior of expectation (Sommer, 2002). For example, when individuals believe that the effects of structural shocks will be permanent, that is what will exactly happen. Again, when individuals believe that the effects of shocks are only impermanent, economic factors swiftly return to their previous position (Ujunwa, 2015). This theory essentially influenced the theoretical framework for this study.

\subsection{Empirical Review}

Several studies have examined the relationship between oil price fluctuation and economic growth of different countries both in and outside Nigeria while some have investigated the relationship on individual countries among Africa's oilproducing countries others did a cross-country analysis. However, their findings are contradictory. For example, (Okonkwo \& Ogbonna, 2018) examined the effect of oil price fluctuations on the Nigerian economy. Dutch disease theory was used to underpin the study. Variables used include crude oil price, GDP, exchange rate, unemployment rate, and government expenditure. These data were gotten from the CBN statistical bulletin and National Bureau of Statistics (NBS) Annual report from 1997-2015. The study reported a linear (direct) relationship among crude oil price, Exchange rate, and unemployment rate, and the Nigerian economy. However, a non-linear (indirect) relationship exists between government expenditure and the Nigerian economy. Notably, only Crude oil prices significantly affected the Nigerian economy. Hence, the researchers suggested that the Nigerian government should strive to diversify the Nigerian economy.

Using the error correction methodology, (Ogbonna \& Orlu, 2017) investigated the impact of petroleum price fluctuation on the Nigerian economy from 1970 to 2013. Variables considered include Premium Motor Spirit (PMS) price, lending interest rate (LIR), labour employment (LEMP), and gross domestic investment (GDI). The studied data was gotten from the CBN Statistical Bulletin and the NBS annual report (2013). The study reported that PMS Price variation exerted a negative insignificant impact on the Nigerian economy. Hence, the study recommends that the Nigerian government should deregulate PMS pump price Again, the private sector should be encouraged to participate actively in the crude oil downstream. 
(Zied et al., 2016) examined the degree of interdependence between oil prices and economic activities of four (4) major (OPEC states from 2000 to 2010. Countries considered include United Arab Emirates, Saudi Arabia, Kuwait, and Venezuela. Using the Engle and Granger co-integration test, the study established that oil price shock exhibited a long-run stable relationship with the economic activities of the countries under investigation.

Employing cointegration and an SVAR model, (Musa, 2015) used quarterly data to analyze the impact of oil price shocks on the growth of the Nigerian economy from 1970-2011. The result confirmed that the oil price shock and unrest are linked to the Nigerian economy in the long run. Further, oil prices, unrest, agricultural output, and exchange rates are strategic in determining the economic growth of Nigeria. However, the study did not capture how the economy can respond to the adverse effect of oil price shocks.

(Donwa et al., 2015) did a study on the relationship between oil price volatility and Nigerian economic growth. The study spanned from 1970-2013 based on both empirical and conceptual literature review of the works of other researchers. Secondary data were sourced from the works of other researchers in addition to those obtained from relevant government agencies, financial institutions, and international organizations like the World Bank, United Nations, and African development bank among others. The study reported that the Nigerian economy in the short run due to high global oil prices, but in the long-run but was inconsistent in the long run due to export concentration. Again, global oil price variation is the reason why the Nigerian economy seems to be unstable. The study also found that Nigeria being a mono-product economy has a special case of Dutch Disease, where a country's seemingly good fortune proves ultimately detrimental to her economy. Certain studies seem to portray Nigeria as suffering from Dutch Disease. (Ijirshar, 2015) posit the importance of oil revenue on the industrialization of the Nigerian state in the long run irrespective of the mismanagement of fund. However, this influence is insignificant in the short run. Also, (Aregbeyen \& Kolawole, 2015) applied OLS, vector error correction (VECM), and granger causality to identify the level of relationship between oil price and its impact on government spending. The result is in the affirmative. This result, therefore, seems dangerous to the nation at this time of high inflation and less need for oil products. It is worthy to note that petroleum products are less needed now due to new technological inventions. The conduct by (Ademola et al., 2015) point to the effect that oil price fluctuation has on inflation. The findings show that oil price fluctuation impacts significantly on inflation. Little wonder Nigeria is experiencing hyperinflation at this time.

Using the survey research design, (Ocheni, 2015) discovered that PMS Price hiking reduces the purchasing power of the Nigerian naira but increased food security. Again, the researcher traced the slow economic propensity of Nigeria to oil sector performance to PMS Price hiking.

Using a multivariate analysis, (Amagoh et al., 2014) examined the implications of PMS variation on some economic fundamentals and discovered that re- 
veals that Petroleum Motor Spirit pump prices, automobile gas oil, and dualpurpose kerosene significantly impacted the Nigerian economy.

(Ani et al., 2014) investigated the effect of crude oil price variation on the $\mathrm{Ni}$ gerian economic development from 1980-2010. The study revealed that crude oil price variation does not significantly affect variation in economic growth (GDP) though both moved linearly. The result agrees with the Dutch Disease theory submissions.

Similarly, (Alley et al., 2014) appraised oil price shocks and Nigerian economic growth over the period 1981-2012. The study revealed that oil price shocks show a negative and inconsequential impact on economic growth, while oil price itself has a positive yet consequential impact on the Nigerian economy. This conforms to the conventional wisdom that oil-rich countries benefit from oil price increase in Nigeria.

Again, (Oyeyemi, 2013) discovered that during the periods of oil price decreases disruption effects occurred in the balance of payments and government finances. Moreover, it was mentioned that even a small shock in global oil prices will have a long-term effect on the economic growth of the country.

(Salim \& Rafiq, 2013) investigated the impact of crude oil price variation on six (6) well-known growing countries in the Asia continent namely China, Indonesia, India, Philippines, Malaysia, and Thailand using quarterly oil price volatility reported. Findings suggested that oil price volatility impacts the economic growth of China only in the short run. However, oil price shock positively affected Indonesia, India, Philippines, Malaysia, and Thailand before and during the Asian financial crisis.

(Nwosa \& Ajibola, 2013) examined the effect of gasoline price on economic sectors in Nigeria from 1980 to 2010. Specifically, the researchers focused on the agricultural; manufacturing; transportation and communication, wholesale and retail, building, and construction sector. The study affirmed that the gasoline price has a long-run consequential impact only on the building and construction sector while in the short run; gasoline price has a consequential impact on the agricultural and the manufacturing sectors.

Using the OLS approach, (Abdul-Rahmoh et al., 2013) discovered that income from petroleum profit tax has a direct yet significant impact on the Nigerian economy from 1970 to 2010. However, (Baghebo \& Atima, 2013) found that petroleum price shock impact economic growth from 1980 to 2011.

Based on the foregoing, the study hypothesizes.

H01: Fluctuation in Oil Price per Barrel does not significantly affect the Nigerian economy;

H02: Petrol Pump Price Fluctuation does not significantly affect the Nigerian economy;

H03: Diesel Pump Price Fluctuation does not significantly affect the Nigerian economy;

H04: Kerosene Pump Price Fluctuation does not significantly affect the Nigerian economy. 


\subsection{Summary of Gaps in the Literature/Critics of the Past Studies}

Sequel to the foregoing, it is noted mentioning that none of these research works focused on the appraisal of the boom, burst as well as sharp declines that have characterized oil price movements over the years. These oil price trends are germane to the economic growth of oil-producing economies of which Nigeria is no exception. This is because it disrupts their policy framework each time it occurs and in most cases, they are tackled with wrong policy ideas, which may aggravate the negative impacts of these unique oil price movements on their macroeconomic performance (GDP) during the period. Again, none of the researchers were able to extend the scope of their studies to 2018 since the most recent scope in the reviewed literature stopped in 2016 (Charfeddine et al., 2018). Also, to date, findings on the subject matter are still contradictory. In light of this exposition, this study tries to share more light on the subject matter by exploring the consequential crude oil fluctuation on the Nigerian economy using a resource dependence approach.

\section{Research Methodology}

This section takes into consideration the research design, study population, sources of data collection, techniques of data analysis, and model specification, and variable measurement.

\subsection{Research Design, Study Population, and Sources of Data Collection}

This paper used the ex post facto research design. Again, we made use of secondary data (time series) from the CBN statistical bulletin, OPEC, and World Bank global financial data spanning from 1984-2018 i.e. 35 years. The CBN bulletin was gotten from the CBN office in Asaba and NSE Onitsha. Data from OPEC and World Bank were sourced from their website. The choice of the period is driven by the availability of data and that the study period takes into account for recession and burst period in Nigeria.

The study population of the study is the whole economy of Nigeria and will be limited to evaluation of the various oil price fluctuation proxies (fluctuation in oil price per barrel, Petrol pump price fluctuation, Diesel pump price fluctuation, and Kerosene pump price fluctuation) in comparison to economic growth proxy (real gross domestic product). The choice of these variables is based on the fact variables are affected by oil fluctuations. The sample size is equivalent to the study population since the researcher fully utilizes the population.

\subsection{Techniques of Data Analysis and Model Specification}

This study adopted the Vector Correction Model through the instrumentality of Econometric Views version 9.0. This technique became amenable for the study because it enabled the researcher to adequately capture the essence of the work effectively in addition to its high level of simplicity and global acceptability. The 
estimation technique began by affirming the valid descriptive characteristics of the studied variables in respect to their mean, median, standard deviation, minimum, maximum, Jarque-Bera, and Skewness. Specifically, the study adopts and modified the empirical model used by (Manasseh et al., 2019; Nwaoha et al., 2018; Charfeddine et al., 2018). The model was used to examine the impact of oil price fluctuation on the growth of Nigeria economy and it is specified as:

$$
\begin{aligned}
& \mathrm{RGDPt}=\alpha_{0}+\alpha_{1} \mathrm{FOPB}+\alpha_{2} \mathrm{PPPF}+\alpha_{3} \mathrm{DPPF}+\alpha_{4} \mathrm{KPPF}+\mathrm{Ut} \\
& \log (\mathrm{RGDPt})=\alpha_{0}+\alpha_{1} \log (\mathrm{FOPB})+\alpha_{2} \log (\mathrm{PPPF}) \\
& +\alpha_{3} \log (\mathrm{DPPF})+\alpha_{4} \log (\mathrm{KPPF})+\mathrm{Ut}
\end{aligned}
$$

where:

$$
\begin{aligned}
& \text { RGDP = Real Gross Domestic Product; } \\
& \text { FOPB = Fluctuation in Oil Price Per Barrel; } \\
& \text { PPPF = Petrol Pump Price Fluctuation; } \\
& \text { DPPF = Diesel Pump Price Fluctuation; } \\
& \text { KPPF = Kerosene Pump Price Fluctuation; } \\
& \alpha_{0}=\text { Intercept; } \\
& \alpha_{1-4}=\text { Coefficient of the Independent variables; } \\
& \text { Ut = Error term. }
\end{aligned}
$$

\section{Aprioiri Expectation}

Theoretically, the coefficient will take the following outcome:

$$
\alpha_{1}>0, \alpha_{2}>0, \alpha_{3}>0, \alpha_{4}>0
$$

Thus, real oil price fluctuation proxies should have a positive effect on real gross domestic product.

\subsection{Variable Measurement}

The variables for the study are summed into two (2): Independent and dependent variables. The Independent variable in the study is oil price fluctuation measured by fluctuation in oil price per barrel, Petrol pump price fluctuation, Diesel pump price fluctuation, and Kerosene pump price fluctuation) while the dependent variable in the study is economic growth measured by RGDP. The choice of these variables is based on the fact variables are affected by oil fluctuations.

They are explained below:

Kerosene Pump Price Fluctuation: This accounts for changes in the average price by consumers of kerosene on yearly basis. This was used for the study to measure oil price fluctuations.

Petrol Pump Price fluctuation: This accounts for both the inward or outward shift in the average price by consumers for premium motor spirit (petrol) on yearly basis. This was used for the study to measure oil price fluctuations.

Fluctuation in Oil Price per Barrel: This accounts for changes in the annual average price of oil in US dollar per barrel. This was used for the study to meas- 
ure oil price fluctuations.

Economic Growth: We used RGDP to measure economic growth. This is a macro-economic measure of the monetary value of all economic outputs taking into account changes in inflation and deflation rate. This is motivated by the fact that unlike nominal GDP, RGDP takes into cognizance inflation and deflation which is a prevalent factor that also affects fluctuation in an economy.

\section{Data Presentation and Description of Data}

This sub-section presents data concerning the relationship between crude oil price fluctuation and economic growth in Nigeria from 1984 to 2018. The data extracted represent crude oil price fluctuation proxies (fluctuation in oil price per barrel, Petrol pump price fluctuation, Diesel pump price fluctuation, and Kerosene pump price fluctuation) with economic growth proxy (real gross domestic product) extracted from CBN statistical bulletin. For this purpose, the data are presented in Table 1 under-leaf are described in Table 2, Figure 1 and Figure 2 under-leaf for ease of discussion of the trends/movement of the variables under study.

\subsection{Data Analysis}

Data for the study was analyzed using descriptive statistics, trend analysis, correlation analysis, unit root test, and ARDL co-integration test.

\subsubsection{Descriptive Statistics}

Table 2 below represents the descriptive statistics in the study. The descriptive statistics presents the numbers of paired observation: mean, median, maximum, minimum and standard deviation values.

The table above shows a summary of the target variables. In other words, it clearly revealed display the interaction between the crude oil price fluctuation and economic performance of Nigeria. Specifically, the numbers of paired observations denoted by "N" accounted for the study period (1984-2018). Also, Table 2 above revealed that real gross domestic product fluctuates by $19,823.87583$ with an average value of $35,495.6997$ as well as a maximum and minimum value of 74,694.00 and 13,779.26 respectively. The Oil price per barrel fluctuates by 35.44644 at an average value of 49.8063 with maximum and minimum values estimated at 116.88 and 14.14 respectively. Again, petroleum (petrol motor spirit) pump price fluctuates by 66.30464 with an average value of 52.1843 as well as a maximum and minimum value of 225.09 and 0.30 respectively. Also, diesel (automotive gas oil) pump price fluctuate by 66.30464 with an average value of 52.1843 as well as a maximum and minimum value of 225.09 and 0.30 respectively. Moreover, kerosene (bonny light crude oil) pump price fluctuate by 74.47973 with an average value of 51.3426 as well as a maximum and minimum value of 290.75 and 0.20 respectively. This suggests that kerosene pump price deviate much away from the mean than other variables. 
Table 1. Raw data on crude oil price fluctuations and economic growth proxy.

\begin{tabular}{|c|c|c|c|c|c|}
\hline Year & $\begin{array}{c}\text { Real Gross } \\
\text { Domestic } \\
\text { Product } \\
\text { (RGDP) }\end{array}$ & $\begin{array}{l}\text { Fluctuation in } \\
\text { Oil Price Per } \\
\text { Barrel (FOPB) }\end{array}$ & $\begin{array}{l}\text { Diesel Pump } \\
\text { Price Fluctua- } \\
\text { tion (DPPF) }\end{array}$ & $\begin{array}{l}\text { Petrol Pump } \\
\text { Price Fluctua- } \\
\text { tion (PPPF) }\end{array}$ & $\begin{array}{c}\text { Kerosene } \\
\text { Pump Price } \\
\text { Fluctuation } \\
\text { (KPPF) }\end{array}$ \\
\hline 1984 & $13,779.26$ & 15.29 & 0.3 & 0.22 & 0.2 \\
\hline 1985 & $14,953.91$ & 19.32 & 0.31 & 0.32 & 0.25 \\
\hline 1986 & $15,237.99$ & 15.88 & 0.35 & 0.39 & 0.36 \\
\hline 1987 & $15,263.93$ & 19.19 & 0.4 & 0.395 & 0.3 \\
\hline 1988 & $16,215.37$ & 23.33 & 0.41 & 0.42 & 0.31 \\
\hline 1989 & $17,294.68$ & 21.39 & 0.48 & 0.6 & 0.4 \\
\hline 1990 & $19,305.63$ & 20.78 & 0.5 & 0.63 & 0.4 \\
\hline 1991 & $19,199.06$ & 18.73 & 1 & 0.7 & 0.5 \\
\hline 1992 & $19,620.19$ & 17.21 & 0.53 & 0.74 & 0.53 \\
\hline 1993 & $19,927.99$ & 18.25 & 0.55 & 3.25 & 2.75 \\
\hline 1994 & $19,979.12$ & 21.95 & 3 & 11.2 & 6.5 \\
\hline 1995 & $20,353.20$ & 20.64 & 9 & 115 & 6.7 \\
\hline 1996 & $21,177.92$ & 14.14 & 9.3 & 11.4 & 6.2 \\
\hline 1997 & $21,789.10$ & 17.63 & 9.5 & 11.5 & 6 \\
\hline 1998 & $22,332.87$ & 30.04 & 9.8 & 11.7 & 6.9 \\
\hline 1999 & $22,449.41$ & 26.55 & 9.9 & 20 & 17.4 \\
\hline 2000 & $23,688.28$ & 26.45 & 19 & 22 & 17.5 \\
\hline 2001 & $25,267.54$ & 31.07 & 21 & 22.4 & 17.7 \\
\hline 2002 & $28,957.71$ & 40.95 & 21.4 & 26 & 24 \\
\hline 2003 & $31,709.45$ & 57.55 & 26 & 40 & 38.1 \\
\hline 2004 & $35,020.55$ & 68.26 & 38 & 49 & 48.7 \\
\hline 2005 & $37,474.95$ & 78.01 & 48 & 65 & 50 \\
\hline 2006 & $39,995.50$ & 104.83 & 60 & 65.3 & 50.5 \\
\hline 2007 & $42,922.41$ & 68.01 & 60.5 & 65.5 & 50.6 \\
\hline 2008 & $46,012.52$ & 83.14 & 60.4 & 65.5 & 50.7 \\
\hline 2009 & $49,856.10$ & 116.43 & 60.6 & 65.6 & 50.4 \\
\hline 2010 & $54,612.26$ & 116.88 & 145 & 65.7 & 50.8 \\
\hline 2011 & $57,511.04$ & 112.87 & 145.3 & 65.9 & 50.9 \\
\hline 2012 & $59,929.89$ & 102.16 & 145.4 & 97 & 75 \\
\hline 2013 & $63,218.72$ & 107.46 & 100 & 97.2 & 150 \\
\hline 2014 & $67,152.79$ & 96.29 & 105 & 97.5 & 129 \\
\hline 2015 & $69,023.93$ & 49.49 & 90 & 87 & 129.5 \\
\hline 2016 & $67,931.24$ & 40.76 & 180 & 145 & 200 \\
\hline 2017 & $68,490.98$ & 52.51 & 220.43 & 145.56 & 267.14 \\
\hline 2018 & $74,694.00$ & 69.78 & 225.09 & 145.92 & 290.75 \\
\hline
\end{tabular}

Source: CBN Statistical Bulletin and annual reports (1984-2018); World Bank Global development Data (1984-2018); OPEC Annual Report (1984-2018). 
Table 2. Descriptive statistics for all the variables under study.

\begin{tabular}{ccccc}
\hline Selected Variables & Minimum & Maximum & Mean & Std. Deviation \\
\hline RGDP & $13,779.26$ & $74,694.00$ & $35,495.6997$ & $19,823.87583$ \\
FOPB & 14.14 & 116.88 & 49.8063 & 35.44644 \\
PPPF & 0.30 & 225.09 & 52.1843 & 66.30464 \\
DPPF & 0.22 & 145.92 & 46.3299 & 46.70591 \\
KPPF & 0.20 & 290.75 & 51.3426 & 74.47973 \\
OBS & 35 & 35 & 35 & 35 \\
\hline
\end{tabular}

Source: Researcher's Computation using E-views Version 9.0 (2020).

\subsubsection{The Trend Analysis}

Figure 1 and Figure 2 below show the trend analysis of the various variables under study over the period of study:

The graphs gave very robust and distinct information on RGDP over the reviewed period. The graph revealed a very low-growth trends between the periods of 1984 to 1990 but thereafter, RGDP grew at a little bit flat rate to 2001 and then increase arithmetically up to 2016 but in 2007 and 2008, there was a little distortion which appears to reflect the impact of the global financial crises that occurred in most economies of the world at that time. However, later experienced upward rise from 2009 to 2012 but also experienced an up-ward-downward slope from 2013 to 2017. Again, the shortfall of 2017 was compensated by an increased RGDP value in 2018.

The graph in Figure 1 above revealed a zigzag movement of oil price per barrel which denotes Fluctuation in the prices of oil per barrel over the period of study. The graph further revealed that the price of oil per barrel was relatively

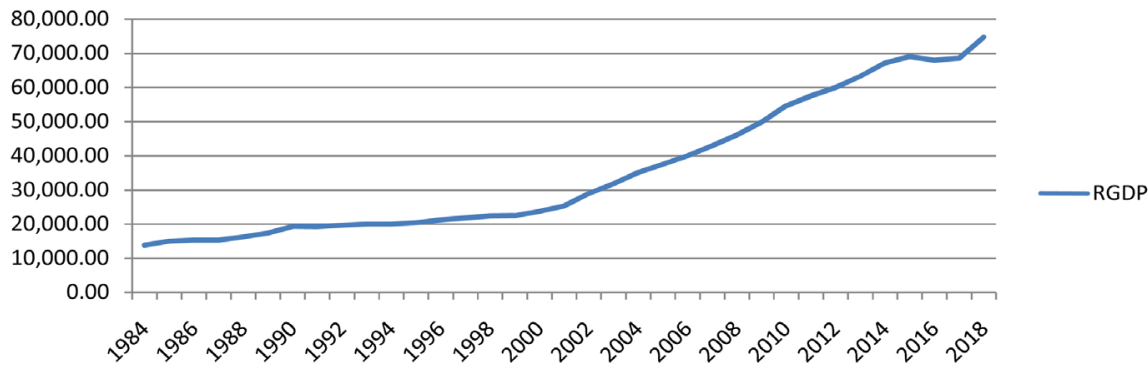

Figure 1. Trend analysis of the economic growth proxy (RGDP). Source: Researcher's compilation based existing data from 1984-2018.

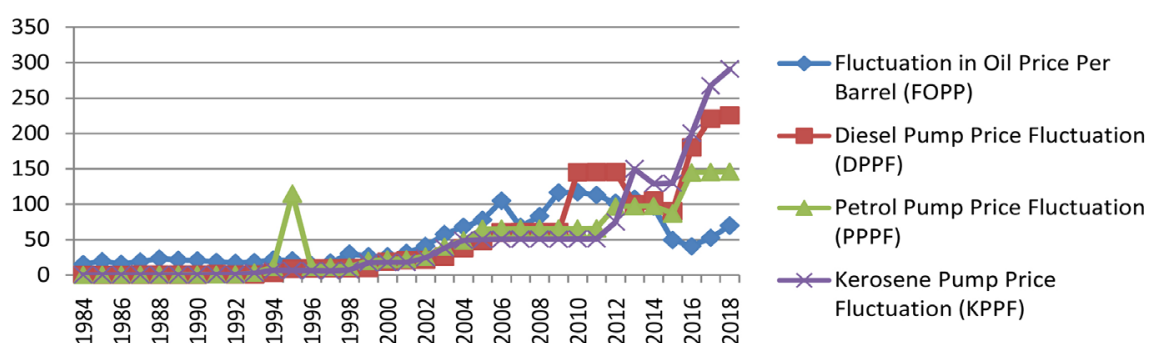

Figure 2. Trend analysis of crude oil fluctuation proxies. Source: Researcher's compilation based existing data from 1984-2018. 
stable from 1984 to 2005 but was affected by the global financial crises of 2007 to 2008 hence the decrease in both periods respectively. Notably, from 2007 up to 2018 , the price of oil price oil per barrel experienced up-downward shift. In addition, the graph in Figure 2 above also revealed a zigzag movement of Premium Motor Spirit which indicates the fluctuation in the price of Petrol. The price was relatively stable from 1984 to 1992 and was at the peak in 1995 and then fell and continues fluctuating from 1996 till 2018. In like manner, Diesel (Automotive gas oil) Pump Price also exhibited zigzag movement throughout the period of study. Meanwhile, the price of Dual Purpose Kerosenein Nigeria indicates fluctuations in the price of Kerosene. The price was relatively stable from 1984 to 1989. It began to rise but was a little bit stable from 2005 to 2011 and then continue rising from 2012 to 2018.

From the foregoing findings, the contrast in the growth trends of RGDP and the explanatory variables appear to suggest a non-correlation relationship and also cast doubts on whether Crude Oil Fluctuation made significant contributions to RGDP in the period under review. Hence, the study sought to investigate if truly this statement is valid.

\subsubsection{Pearson Correlation}

Pearson Correlation depicts the strength of linearity among variables under investigation. From the Pearson Correlation Coefficient Matrix table, it is observed that the correlation coefficients between RGDP and most of the independent variables are relatively very high suggesting a strong relationship between them. For example, the correlation coefficient among Real Gross Domestic Product (RGDP) and Oil Price per Barrel (FOPB), Diesel Pump Price Fluctuation (PPPF), and Petrol Pump Price Fluctuation (DPPF) stood at 0.801241, 0.889669, and 0.843803 respectively indicating that the linear relationship between RGDP and those independent variables are $80.12 \%, 88.97 \%$, and $84.38 \%$ respectively. More so, the correlation coefficient between RGDP and Kerosene Pump Price Fluctuation (KPPF) stood at 0.465858 meaning a linear relationship of $46.59 \%$ is also outstanding. On overall, the Pearson Correlation result revealed that crude oil fluctuation has a positive strong relationship with economic growth over the study period. However, this result of positive relationship therefore counters the aprioiri expectation of negative relationship between crude oil fluctuation and economic growth (Table 3 ).

Table 3. Pearson correlation coefficient matrix of variables.

\begin{tabular}{cccccc}
\hline & RGDP & FOPB & DPPF & PPPF & KPPF \\
\hline RGDP & 1.000000 & & & & \\
FOPB & 0.801241 & 1.000000 & & & \\
DPPF & 0.889669 & 0.626324 & 1.000000 & & \\
PPPF & 0.843803 & 0.670734 & 0.679758 & 1.000000 & \\
KPPF & 0.465858 & 0.171245 & 0.586757 & 0.366994 & 1.000000 \\
\hline
\end{tabular}

Source: Researcher's computation using e-views version 9.0 (2020). 


\subsubsection{Unit Root Test}

Originally, economic data are assumed to possess some form of stationarity. However, it is paramount to ascertain if the statement is true in all respects. In doing this, we used the Augmented Dicker Fuller Test to check whether the data series are stationary (both at levels and first difference) or not. Hence, to check whether a particular data series attain stationarity, we compared the ADF test statistics with the MacKinnon critical value. Wherein the ADF statistics is greater than the critical values, the decision rule is to reject the null hypothesis of the presence of unit root and accept the alternative hypothesis which assume that the data series possess stationary and vice versa. The ADF test is presented below:

Table 4 above clearly revealed that all the study variables except real gross domestic product possess unit root at their natural levels. This is because, at their natural levels, their respective ADF test statistics were less than their MacKinnon critical values at $5 \%$ significant level. Again, their respective p-values were also greater 5\% significant level. For example, the ADF test statistics for Oil Price per Barrel (FOPB), Diesel Pump Price Fluctuation (PPPF), Kerosene Pump Price Fluctuation (KPPF), and Petrol Pump Price Fluctuation (DPPF) stood at

Table 4. Unit root test for all study variables.

\begin{tabular}{|c|c|c|c|c|c|}
\hline \multicolumn{6}{|c|}{ AT LEVELS } \\
\hline $\begin{array}{c}\text { Study } \\
\text { Variables }\end{array}$ & $\begin{array}{l}\text { ADF Test } \\
\text { Statistics }\end{array}$ & $\begin{array}{c}\text { MacKinnon } \\
\text { Critical Value } \\
@ 5 \% \text { level }\end{array}$ & $\mathrm{P}$-value & $\begin{array}{c}\text { Order of } \\
\text { Integration }\end{array}$ & Conclusion \\
\hline LOG(RGDP) & -3.469531 & -2.954021 & 0.0154 & $1(0)$ & Stationary \\
\hline LOG(FOPB) & -1.236435 & -2.951125 & 0.6470 & $1(0)$ & $\begin{array}{c}\text { Presence of } \\
\text { Unit Root }\end{array}$ \\
\hline LOG(DPPF) & -0.937740 & -2.951125 & 0.7637 & $1(0)$ & $\begin{array}{c}\text { Presence of } \\
\text { Unit Root }\end{array}$ \\
\hline LOG(KPPF) & -0.992247 & -2.951125 & 0.7449 & $1(0)$ & $\begin{array}{c}\text { Presence of } \\
\text { Unit Root }\end{array}$ \\
\hline LOG(PPPF) & -1.601072 & -2.951125 & 0.4711 & $1(0)$ & \\
\hline \multicolumn{6}{|c|}{ AT FIRST DIFFERENCE } \\
\hline $\begin{array}{c}\text { Study } \\
\text { Variables }\end{array}$ & $\begin{array}{l}\text { ADF Test } \\
\text { Statistics }\end{array}$ & $\begin{array}{c}\text { MacKinnon } \\
\text { Critical Value } \\
@ 5 \% \text { level }\end{array}$ & $\mathrm{P}$-value & $\begin{array}{c}\text { Order of } \\
\text { Integration }\end{array}$ & Conclusion \\
\hline LOG(RGDP) & -6.683186 & -2.957110 & 0.0000 & $1(1)$ & Stationary \\
\hline LOG(FOPB) & -4.913071 & -2.957110 & 0.0004 & $1(1)$ & Stationary \\
\hline LOG(DPPF) & -5.261112 & -2.954021 & 0.0001 & $1(1)$ & Stationary \\
\hline LOG(KPPF) & -4.687622 & -2.954021 & 0.0007 & $1(1)$ & Stationary \\
\hline LOG(PPPF) & -6.157853 & -2.954021 & 0.0000 & $1(1)$ & Stationary \\
\hline
\end{tabular}

Source: Researcher's computation based on e-views 9.0 (2020). 
$1.236435,-0.937740,-0.992247$, and -1.601072 . Meanwhile their respective MacKinnon critical values are $-2.951125,-2.951125,-2.951125$, and -2.951125 respectively. However, when subjected to further testing, Oil Price per Barrel (FOBP), Diesel Pump Price Fluctuation (PPPF), Kerosene Pump Price Fluctuation (KPPF), and Petrol Pump Price Fluctuation (DPPF)attained stationarity at first difference as evidenced by their respective high ADF test Statistics, low MacKinnon critical values, and low p-values. Hence, it is therefore imperative to check for the long run relationship among the study variables.

\subsubsection{ARDL Bound Cointegration Test}

Since all the study variables attained stationary both at their natural levels and first difference, the Auto-regressive Distributed Lag model is deemed fit for the study. The result is present below:

The cointegration result in Table 5 above clearly revealed that there is longrun statistical relationship between crude oil fluctuation proxies and economic performance of Nigeria throughout the period of study. This is because the calculated F-statistic value estimated at 4.050202 is greater than the critical bound value estimated at 4.01. To ensure that the model is robust, we subjected the model to diagnostic test before proceeding to the main result. The results are therefore presented in Table 6, Table 7 below:

The Heteroskedasticity test in Table 6 above reported that the p-value of the f-statistics is greater than $5 \%$ significance level. Hence, we rejected the null hypothesis of presence of Heteroskedasticity and accepted the alternative hypothesis of homoskedasticity (equal variance). As such, we concluded that the model is Homoskedastic. This further reaffirmed the classical OLS assumption of homoskedasticity (equal variance).

The Ramsey RESET Test in Table 7 above revealed that none of the variables are omitted and that the model is correctly specified. As such, the model can be depended upon for statistical inferences.

Table 5. ARDL bound co-integration test.

Sample: 1986-2018

Included observations: 33

Null Hypothesis: No long-run relationships exist

\begin{tabular}{ccc}
\hline Test Statistic & Value & K \\
\hline F-statistic & 4.050202 & 4 \\
\hline Significance & Critical Value Bounds & \\
\hline $10 \%$ & I0 Bound & I1 Bound \\
$5 \%$ & 2.45 & 3.52 \\
$2.5 \%$ & 2.86 & 4.01 \\
$1 \%$ & 3.25 & 4.49 \\
\hline
\end{tabular}

Source: Researcher's computation based on e-views 9.0 (2020). 
Table 6. Heteroskedasticity test: Breusch-Pagan-Godfrey.

\begin{tabular}{cccc}
\hline F-statistic & 1.033226 & Prob. F (4,29) & 0.4069 \\
Obs ${ }^{\star}$ R-squared & 4.241063 & Prob. Chi-Square (4) & 0.3744 \\
Scaled explained SS & 3.372664 & Prob. Chi-Square (4) & 0.4975 \\
\hline
\end{tabular}

Source: Researcher's computation based on e-views 9.0 (2020).

Table 7. Ramsey reset test.

\begin{tabular}{|c|c|c|c|}
\hline \multicolumn{4}{|c|}{ Equation: UNTITLED } \\
\hline \multicolumn{4}{|c|}{ Specification: LOG(RGDP) C LOG(FOPB) LOG(DPPF) LOG(KPPF) LOG(PPPF) } \\
\hline \multicolumn{4}{|c|}{ Omitted Variables: Squares of fitted values } \\
\hline & Value & Df & Probability \\
\hline t-statistic & 0.151596 & 26 & 0.8807 \\
\hline F-statistic & 0.022981 & $(1,26)$ & 0.8807 \\
\hline Likelihood ratio & 0.010181 & 1 & 0.9196 \\
\hline \multicolumn{4}{|l|}{ F-test summary: } \\
\hline & Sum of Sq. & Df & Mean Squares \\
\hline Test SSR & $2.59 \mathrm{E}-05$ & 1 & $2.59 \mathrm{E}-05$ \\
\hline Restricted SSR & 0.029300 & 27 & 0.001085 \\
\hline Unrestricted SSR & 0.029275 & 26 & 0.001126 \\
\hline
\end{tabular}

Source: Researcher's computation based on e-views 9.0 (2020).

\subsection{Regression Result}

This section covers both the ARDL Cointegrating (short run) and long run analysis. The result is presented below:

\subsection{Discussions/Managerial Implications}

From Table 8 above, Fluctuation in Oil Price per Barrel (FOPB), with t-test coefficients of 4.194789 passed the test of significance at 5\% significant level is showing that they are relevant in formulating policies that affect RGDP on the short run. However, the t-test coefficient of some other independent variables such as Diesel Pump Price Fluctuation (PPPF) standing at -0.775452; Kerosene Pump Price Fluctuation (KPPF) standing at -0.339885 ; and Petrol Pump Price Fluctuation (DPPF) standing at -1.303260 were not relevant in formulating policies because their coefficients exhibit weak relationship with RGDP. That-not-withstanding, the negative sign of Diesel Pump Price Fluctuation (PPPF), Kerosene Pump Price Fluctuation (KPPF), and Petrol Pump Price Fluctuation (DPPF) conformed to apriori expectation of the study while the rest independent variable counters the apriori expectation of the study. This means that Diesel Pump Price Fluctuation (PPPF), Kerosene Pump Price Fluctuation (KPPF), and Petrol Pump Price Fluctuation (DPPF) which ought to contribute to decrease in RGDP in Nigeria as an oil endowed nation is contributing to 
Table 8. ARDL cointegrating and long run form.

\begin{tabular}{|c|c|c|c|c|}
\hline \multicolumn{5}{|c|}{ Dependent Variable: LOG(RGDP) } \\
\hline \multicolumn{5}{|c|}{ Selected Model: ARDL $(1,0,0,1,0)$} \\
\hline \multicolumn{5}{|c|}{ Date: 09/20/20 Time: $15: 58$} \\
\hline \multicolumn{5}{|l|}{ Sample: 19842018} \\
\hline \multicolumn{5}{|c|}{ Included observations: 34} \\
\hline \multicolumn{5}{|l|}{ Cointegrating Form } \\
\hline Variable & Coefficient & Std. Error & $\mathrm{t}$-Statistic & Prob. \\
\hline DLOG(FOPB) & 0.056193 & 0.013396 & 4.194789 & $0.0003^{*}$ \\
\hline DLOG(DPPF) & -0.012896 & 0.016630 & -0.775452 & 0.4448 \\
\hline DLOG(KPPF) & -0.005623 & 0.016543 & -0.339885 & 0.7366 \\
\hline DLOG(PPPF) & -0.014854 & 0.011398 & -1.303260 & 0.2035 \\
\hline CointEq $(-1)$ & -0.088586 & 0.028614 & -3.095876 & 0.0045 \\
\hline \multicolumn{5}{|c|}{ Cointeq $=\mathrm{LOG}(\mathrm{RGDP})-(0.6343 * \mathrm{LOG}(\mathrm{FOPP})-0.1456 * \mathrm{LOG}(\mathrm{DPPF})$} \\
\hline \multicolumn{5}{|c|}{$+0.3763 * \mathrm{LOG}(\mathrm{KPPF})-0.1677 * \mathrm{LOG}(\mathrm{PPPF})+8.5113)$} \\
\hline \multicolumn{5}{|c|}{ Long Run Coefficients } \\
\hline Variable & Coefficient & Std. Error & t-Statistic & Prob. \\
\hline LOG(FOPB) & 0.634337 & 0.213285 & 2.974132 & $0.0061^{*}$ \\
\hline LOG(DPPF) & -0.145577 & 0.204172 & -0.713011 & 0.4820 \\
\hline LOG(KPPF) & 0.376277 & 0.182731 & 2.059188 & $0.0492^{*}$ \\
\hline LOG(PPPF) & -0.167683 & 0.114188 & -1.468484 & 0.1535 \\
\hline C & 8.511334 & 0.535987 & 15.879727 & 0.0000 \\
\hline R-squared & 0.997767 & \multicolumn{2}{|c|}{ Mean dependent var } & 10.35214 \\
\hline Adjusted R-squared & 0.997271 & \multicolumn{2}{|c|}{ S.D. dependent var } & 0.540126 \\
\hline S.E. of regression & 0.028218 & \multicolumn{2}{|c|}{ Akaike info criterion } & -4.116476 \\
\hline Sum squared resid & 0.021499 & \multicolumn{2}{|c|}{ Schwarz criterion } & -3.802225 \\
\hline Log likelihood & 76.98009 & \multicolumn{2}{|c|}{ Hannan-Quinn criter. } & -4.009308 \\
\hline F-statistic & 2010.623 & \multicolumn{2}{|c|}{ Durbin-Watson stat } & 1.726509 \\
\hline Prob(F-statistic) & 0.000000 & & & \\
\hline
\end{tabular}

Source: Researcher’s computation based on e-views 9.0 (2020). * Significant P values.

increase in RGDP in Nigeria. The policy implication of this result is that a unit rise in Diesel Pump Price Fluctuation (PPPF), Kerosene Pump Price Fluctuation (KPPF), and Petrol Pump Price Fluctuation (DPPF) will lead to a corresponding decrease of $1.29 \%, 0.56 \%$, and $1.49 \%$ in economic progress. However, its impact on the Nigerian economy tends to be minimal (insignificant). Again, a unit rise in Fluctuation in Oil Price per Barrelleads to a corresponding rise of about $5.62 \%$ in economic progress. This is not farfetched in that a cursory look at the data presented in Table 8 above revealed an upward rise in those variables. 
Hence, the positive report.

The long run result clearly revealed that only Fluctuation in Oil Price per Barrel and Kerosene Pump Price Fluctuation (KPPF) passed the test of significance. Also, both variables were positive. Meanwhile, Diesel Pump Price Fluctuation (PPPF), and Petrol Pump Price Fluctuation (DPPF) have negative insignificant impacts on economic progress.

Furthermore, the short run dynamics revealed that the model is rightly signed since the coefficient of the Cointegrating equation is less than 1 , negative, and is statistically significant. This indicates that the variables converge after short run disequilibrium. Result indicates that $8.86 \%$ of past deviation is corrected in the current period. In the same vein, the F-statistics indicates that on the overall crude oil price fluctuation has significant on economic performance of Nigeria. Also, the R-squared (coefficient of determination) being the square root of the coefficient of correlation (R) above shows that $99.78 \%$ of the total variation in the RGDP is elucidated by crude oil fluctuation. To further buttress this, the Adjusted R-Square which gives more explanation of the explanatory power of the model revealed that $99.73 \%$ of the total variation in (RGDP) is explained by all crude oil fluctuation proxies under study while the remaining significant value of $0.27 \%$ is attributed to other factors which affect crude oil price fluctuation not captured in the study but was captured by the error term. This suggests that the model retains its optimal Best Linear Unbiased Estimate (BLUE) property.

Lastly, the model is free from serial autocorrelation given that the Durbin Watson Statistics (approximately 2) is within the acceptable bound. Notably, despite the difference in study approach, the finding of this study agrees with the findings of (Okonkwo \& Ogbonna, 2018; Nwaoha et al., 2018; Musa, 2015; Donwa et al., 2015). These studies observed that petroleum pump price increase have statistical significant impact on economic growth in Nigeria. However, the finding of this study contradicts with the findings of (Charfeddine et al., 2018).

\section{Conclusion and Recommendations}

The conclusion reached from this study is that on the overall, crude oil fluctuation vis-à-vis Fluctuation in Oil Price per Barrel (FOBP), Diesel Pump Price Fluctuations (PPPF), Petrol Pump Price Fluctuations (DPPF), and Kerosene Pump Price Fluctuation (KPPF) exert positive and significant effects on economic performance of Nigeria. Particularly, the t-statistics revealed that only Fluctuation in Oil Price per Barrel (FOBP), exert positive and significant effects on economic growth in the short run while in the long run both Fluctuation in Oil Price per Barrel (FOBP) and Kerosene Pump Price Fluctuation (KPPF) improve the Nigerian economy significantly. Hence we conclude that, if Nigerian economy must grow it should examine the crude oil fluctuation proxies jointly. In line with the findings of the study, we hereby recommend the following: $\mathrm{Ni}$ gerian government should ensure that individuals should not interfere over the apex bank surveillance over the excess crude account; The federal government 
should fix the existing local refineries and ensure that they are working at full capacity level with a view to avoiding over-dependence so as to encourage zero import expenditure on finished petroleum products; Effort should be made to deregulate the oil downstream sector. The federal government should ensure that the current diesel pump price should be reduced to the barest minimum with a view to achieving sustainable economic growth; Effort should be made to diversifies and industrialize the Nigerian economy; The federal government should introduce strict measures that will severely deal with citizens who smuggle, hoard, and create artificial scarcity and black marketers of crude oil products so as to make an abnormal profit to the detriment of the whole country; Nigerian Government should ensure that they carry along with trade unions, Labour Union, as well as other private sectors before it reduces the prices of Diesel product in Nigeria since it tends to have a detrimental effect on the economic prowess of Nigeria. Once all these policy recommendations cited above are put in place, the macro-economic objective of sustainable economic growth would be fully attained.

\section{Conflicts of Interest}

The authors declare no conflicts of interest regarding the publication of this paper.

\section{References}

Abdul-Rahamoh, O. A., Taiwo, F. H., \& Adejere, A. T. (2013). The Analysis of the Effect of Petroleum Profit Tax on Nigerian Economy. Asian Journal of Humanities and Social Sciences, 1, 25-36.

Ademola, I. S., Olasode, O. S., Raji, O. A., \& Adedoyin, A. O. (2015). Government Expenditure, Oil Revenue and Economic Growth in Nigeria. International Journal of Economics, Commerce and Management, 3, 180-202.

Adugbo, D. (2016). Nigeria: Oil Price Fall-How the Mighty Are Crawling. Daily Trust. http://www.allafrica.com/stories/201601130544.html

Akinleye, S. O., \& Ekpo, S. (2013). Oil Price Shocks and Macroeconomic Performance in Nigeria. Economía Mexicana Nueva Época, 1, 565-624.

Akinlo, A. E. (2012). How Important Is Oil in Nigeria's Economic Growth? Journal of Sustainable Development, 5, 165-179. https://doi.org/10.5539/jsd.v5n4p165

Alley, I., Asekomeh, A., Mobolaji, H., \& Adeniran, Y. A. (2014). Oil Price Shocks and the Nigerian Economy Growth. European Scientific Journal, 10, 375-391.

Amagoh, M. N., Odoh, C. M., \& Okuh, B. A. (2014). Modelling Petroleum Product Prices and the Nigerian Economy. IOSR Journal of Mathematics (ISOR-JM), 10, 72-79. https://doi.org/10.9790/5728-10147279

Ani, W., Ugwunta, D., Inyiama, O., \& Eneje, B. (2014). Oil Price Volatility and Economic Development: Stylized Evidence in Nigeria. Journal of Economics and International Finance, 6, 125-133. https://doi.org/10.5897/JEIF2014.0572

Apere, O. T., \& Ijeoma, A. M. (2013). Macroeconomic Impact of Oil Price Levels and Volatility in Nigeria. International Journal of Academics and Research in Economic for Management Sciences, 2, 15-25. https://doi.org/10.6007/IJAREMS/v2-i4/48 
Aregbeyen, O., \& Kolawole, B. O. (2015). Oil Revenue, Public Spending and Economic Growth Relationships in Nigeria. Journal of Sustainable Development, 8, 113-123. https://doi.org/10.5539/jsd.v8n3p113

Aremo, A. G., Orisadare, M. A., \& Ekperiware, C. M. (2012). Oil Price Shocks and Fiscal Policy Management: Implication for Nigerian Economic Planning. International Journal of Development and Sustainability, 1, 1121-1139.

Armando, F. D. (2009). Latin American Structuralism and Economic Theory. CEPAL Review, No. 98, 175-195. https://doi.org/10.18356/9e69f49e-en

Arnason, R. (2008). Natural Resource Rents: Theoretical Clarification. Working Paper Series W08:07, Paris: Institute of Economic Studies.

Baghebo, M., \& Atima, T. O. (2013). The Impact of Petroleum on Economic Growth in Nigeria. Global Business and Economic Journal, 2, 102-115.

Ball, L., \& Mankiw, N. G. (1995). Relative-Price Changes as Aggregate Supply Shocks. Quarterly Journal of Economics, 110, 161-193. https://doi.org/10.2307/2118514

Baumeister, C., \& Kilian, L. (2016). Forty Years of Oil Price Fluctuations: Why the Price of Oil May Still Surprise Us. Journal of Economic Perspectives, 30, 139-160.

https://doi.org/10.1257/jep.30.1.139

CBN (2014). Statistical Bulletin (Vol. 21). Abuja: Central Bank of Nigeria.

Charfeddine, L., Klein, T., \& Walther, T. (2018). Oil Price Changes and US Real GDP Growth: Is This Time Different (p. 1)? Working Paper Version 2.0. https://doi.org/10.2139/ssrn.3222572

Corden, W. M., \& Neary, J. P. (1982). Booming Sector and De-Industrialisation in a Small Open Economy. Economic Journal, 92, 825-848. https://doi.org/10.2307/2232670

Donwa, P. A., Mgbame, C. O., \& Onyeoweni, S. I. (2015). Impact of Oil Price Volatility on Economic Growth: Conceptual Perspective. International Journal of Multidisciplinary Research and Development, 2, 80-85.

Environmental Impact Assessment (EIA) (2011). Guidance on the Preparation on the EIA. https://ec.europa.eu/environment/eia/pdf/EIA_guidance_EIA_report_final.pdf

Fischer, S. (1985). Supply Shock, Wage Stickiness and Accommodation. Journal of Money, Credit, and Banking, 17, 1-15. https://doi.org/10.2307/1992502

Husain, A. M., Arezki, R., Breuer, P., Haksar, V., Thomas, H., Paulo, M. A., \& Martin, S. (2015). Global Implications of Lower Oil Prices.

https://doi.org/10.5089/9781513532417.006

https://www.imf.org/en/Publications/Staff-Discussion-Notes/Issues/2016/12/31/Global -Implications-of-Lower-Oil-Prices-43052

Ijirshar, V. U. (2015). The Empirical Analysis of Oil Revenue and Industrial Growth in Nigeria. African Journal of Business Management, 9, 599-607. https://doi.org/10.5897/AJBM2015.7801

IMF (2016). International Monetary Fund Economic Report: Africa Focus. Special Issue, No. 49, 1-29. https://doi.org/10.5089/9781498399746.002

Inflation Report (2006). Nigeria's 2006 Inflation Rate. https://nairametrics.com/2016/02/08/nigerias-2006-inflation-rate/

Ismail, K. (2021). The Structural Manifestation of the 'Dutch disease': the Case of Oil Exporting Countries.

https://www.imf.org/en/Publications/WP/Issues/2016/12/31/The-Structural-Manifestat ion-of-the-Dutch-Disease-The-Case-of-Oil-Exporting-Countries-23801

Keji, S. A. (2018). An Empirical Nexus between Oil Price Collapse and Economic Growth in Sub-Saharan African Oil Based Economies. Journal Perspektif Penbiayaandau Pem- 
bangunan Daerah, 5, 300-313.

Krueger, A. O. (1974). The Political Economy of the Rent-Seeking Society. The American Economic Review, 64, 291-303.

Lee, K., Ni, S., \& Ratti, R. A. (1995). Oil Shocks and the Macro-Economy: The Role of Price Variability. Energy Journal, 16, 39-56. https://doi.org/10.5547/ISSN0195-6574-EJ-Vol16-No4-2

Manasseh, C. O., Abada, F. O., Ogbuabo, F. O., Okoro E. U., Egele, A. J., \& Ozuzu, K. E. (2019). Oil Price Fluctuation, Oil Revenue and Well-Being in Nigeria. International Journal of Energy Economics and Policy, 9, 346-355.

Mustapha, S. A., \& Sulaiman, L. A. (2015). Estimating the Critical Bands for Nigeria's Crude Oil Price and Production: Evidence from GARCH Models and Internal Adjustments. Procedia Economics and Finance, 30, 573-585.

https://doi.org/10.1016/S2212-5671(15)01270-8

Nwanna, I. O., \& Eyedayi, A. M. (2016). Impact of Crude Oil Price Volatility on Economic Growth in Nigeria (1980-2014). IOSR Journal of Business and Management (IOSR-JBM), 18, 10-19.

Nwaoha, W. C., Onwuka, O. O., Ejem, C. A., Obisike, N. E., \& Ogbuewu, K. J. (2018). Movements of Petroleum Pump Prices and Standard of Living: Evidence from Nigeria. International Journal of Social Sciences and Management Research, 4, 57-67.

Nwosa, P. I., \& Ajibola, A. A. (2013). The Effect of Gasoline Price on Economic Sectors in Nigeria. International Journal of Energy Economics and Policy, 3, 99-110.

Ocheni, S. I. (2015). Impact of Fuel Price Increase on the Nigerian Economy. Mediterranean Journal of Social Sciences, 6, 560-569. https://doi.org/10.5901/mjss.2015.v6n1s1p560

Ogbonna, G. N., \& Appah, E. (2012). Petroleum Income and Nigerian Economy: Empirical Evidence. Arabian Journal of Business and Management Review, 1, 33-59. https://doi.org/10.12816/0002159

Ogbonna, G. N., \& Orlu, R. N. (2017). The Impact of Domestic Pricing of Petrol on Economic Growth of Nigeria (1970-2013). Global Journal of Social Sciences, 16, 1-8. https://doi.org/10.4314/gjss.v16i1.1

Ogiri, H. I., Amadi, S. N., Uddin, M. M., \& Dubon, P. (2013). Oil Prices and Stock Market Performance in Nigeria: An Empirical Analysis. American Journal of Social and Management Sciences, 4, 20-41.

Okonkwo, I. V., \& Mojekwu, K. O. (2018). Crude Oil Price Fluctuations and Nigeria Economic Growth: 1997-2015. International Journal of Research in Business, Economics and Management, 2, 48-61.

Okonkwo, I. V., \& Ogbonna, M. K. (2018). Crude Oil Price Fluctuations and Nigeria Economic Growth: 1997-2015. International Journal of Research in Business, Economics and Management, 2, 44-61.

Oyeyemi, A. M. (2013). The Growth Implications of Oil Price Shock in Nigeria. Journal of Emerging Trends in Economics and Management Sciences, 4, 343-349.

Pindyck, R. S. (1979). The Structure of World Energy Demand Cambridge. MIT Press.

Rentschler, J. E. (2013). Oil Price Volatility, Economic Growth and the Hedging Role of Renewable Energies. Policy Research Working Paper 6603, Washington DC: World Bank. https://doi.org/10.1596/1813-9450-6603

Ross, M. (2001). Timber Booms and Institutional Breakdown in Southeast Asia. Cambridge: Cambridge University Press. https://doi.org/10.1017/CBO9780511510359

Salim, R., \& Rafiq, S. (2013). The Impact of Crude Oil Price Volatility on Selected Asian 
Emerging Economies. Journal of Development Economics, 51, 1-33.

Sommer, M. (2002). Supply Shocks and Persistence of Inflation. Economics Working Paper Archive 485, Baltimore, MD: The Johns Hopkins University, Department of Economics.

Udoh, M. D. (2014). The Impact of Foreign Direct Investment and Oil Exports on Economic Growth in Nigeria. Research on Humanities and Social Sciences, 4, 1-10.

Udoka, C. O., \& Nkamare, S. E. (2014). The Implication of Crude Oil Glut on the Performance of the Nigeria Capital Market. Journal of Business Management, 18, 11-23.

Ujunwa, A. (2015). Macroeconomic Effects of Exogenous Oil Price Shock in Nigeria: Persistent or Transitory. Nsukka: Department Banking and Finance, University of Nigeria, Enugu Campus.

Usman, A., Madu, I., \& Abdullahi, F. (2015). Evidence of Petroleum Resources on Nigerian Economic Development (2000-2009). Business Economics Journal, 6, 2. https://doi.org/10.4172/2151-6219.1000149

World Bank (2015). World Development Indicators. Washington DC: World Bank.

Zied, F., Khaled, G., Frédéric, T., \& Slim, C. (2016). Relationship between Crude Oil Prices and Economic Growth in Selected OPEC Countries. The Journal of Applied Business Research, 32, 1-22. 